Journal of Social Sciences 6 (3): 376-382, 2010

ISSN 1549-3652

(C) 2010 Science Publications

\title{
Activity-Based Costing in the Public Sector
}

\author{
Athanasios Vazakidis, Ioannis Karagiannis and Anthi Tsialta \\ Department of Applied Informatics, University of Macedonia, \\ Egnatia 156, P.O. Box 1591, 540 06, Thessaloniki, Greece,
}

\begin{abstract}
Problem statement: In the modern economic environment, the Public Sector aims at the continuous improvement of quality of the provided services. Thus, detailed information with regard to the cost of services is essential along with capable management to take advantage of this information. Approach: The study discussed the basic beginnings, the processes of activity-based costing and whether this costing method can be applied in the Public Sector, where the need for precise cost estimating information increases continuously. Results: It referred to the structure of a Greek Prefecture, with all the organized divisions and departments. At first, the new method of cost accounting is analyzed as mentioned in the international bibliography. Thereafter, the advantages of this method were pointed and then, follow the application in a specific Department of the prefecture where the results were delivered to the Administration of department under review, for the decisionmaking. Conclusion: Having analyzed the department of the prefecture, the management can depend on the results to comment on the study done and decide on future plans.
\end{abstract}

Key words: Activity-based costing, cost of services, public sector, activity-based costing in the public sector and cost of service organizations

\section{INTRODUCTION}

It has been analyzed that more than $60 \%$ of all citizen transactions are done through Prefecture (Local Government), so its basic role cannot be other than to serve citizens (Tsialta, 2009).

Even though a lot of positive steps have been made during the recent years in the Public Administration (Public Sector) in Greece, mainly by using new technologies, the current reality in the public administration continues to be characterized of bureaucracy, absence of strategic action, wastefulness of management of public resources, corruptness and absence of rational designing of places of study.

As an aftermath of all the above, is the cost of the provided services that overcome the benefit that the citizen receives, meaning that these services are too expensive and usually of low quality. The standardization and the simplification of administrative processes (services) can constitute one of the more powerful mechanisms of transparency and confrontation of corruptness. Cost accounting (in our research Activity-Based Costing) can participate in this change by analyzing each part of the Local Government and in combination with appropriate manpower planning and management of the necessary resources, this mechanism can make the difference.
Activity-based costing:

Definition: Activity-Based Costing is a costing method based on all activities and functions that participate in a company. This method allows cost-accountants to assign all overhead cost (those that cannot be apportioned directly to the products) to the activities that take place in an organization and then these activities with the help of activity-drivers are assigned to the products-services produced. The result is to have full information about the cost of products made.

According to Kirche (2002), the activities are categorized in unity, batch and order related activities:

- The unity-level activities are those that have to be performed for every unit of product or service produced

- The batch-level activities are those that have to be performed for each batch or setup of study performed

- The order-related activities are those that enable the production of individual orders (or services) to occur. Examples include maintaining design and specification and special testing and tooling for individual orders

Literature review: From 1970s Activity-Based Costing (ABC) was mainly developed to serve

Corresponding Author: Athanasios Vazakidis, Department of Applied Informatics, University of Macedonia, Egnatia 156, P.O. Box 1591, 540 06, Thessaloniki, Greece Tel: 2310891863 
industrial companies, but from the early years of its development, researchers have investigated the possibility of using it in the service sector as well.

Kaplan (1994) reports that in the early 1980 ABC was already used in the service sector by logistics companies, by banks and hospitals and had already developed costing models similar to the ABC.

King (1995) has made four research attempts in the hospitals of England, where it concluded also that the British National Health System (NHS) can benefit from the implementation of $\mathrm{ABC}$, because it is a method that can easily adapt in the specific needs and particularities of each institution.

Moreover, Brimson and Antos (1994) mention examples of American Public Sectors where ActivityBased Costing succeeded when used. The writers quote that Activity-Based Costing has been implemented in telecommunication companies, parcel post companies, hospitals, electricity and gas companies, helping them control their cost and letting management concentrate on their customers.

Evans and Bellamy (1995) argue the necessity of developing this new method in order to cost the services of Public Sector for a better management, even though traditional methods are still in use. In Greece, Kostopoulos et al. (2003), apply the new method in the Open Psychiatric Center of Athens Greece. Their aim is to acquire information relative to the service cost of the therapeutic organization and the service cost of the psychotherapy for the patients. The results provide the information of the minimum cost of each psychotherapy session and the minimum amount of patients for the economic self-sufficiency of the Psychiatric not-profitable unit.

Moreover, the Municipality of Argyroupolis (Municipality of Argyroupolis, 2005) in Athens Greece, via its internet site, claims that it applies the method of Activity-Based Costing since 2005, in order to better monitor and control various elements of cost that absorbs the enterprise at its every activity.

In the Macedonia University of Thessaloniki Greece, Vazakidis and Karagiannis (2006) present completed studies and articles which are published in journals and congresses. In 2006, they have presented for the first time a model of cost accounting for the Department of Applied Informatics of University of Macedonia in Thessalonica, more for internal information and then for the promotion of this new method in the Greek environment (Vazakidis and Karagiannis, 2006). Finally in 2008, they applied a new model of Activity-Based Costing and Activity-Based Management in a tourist organization (Vazakidis and
Karagiannis, 2009), so as to point out the usefulness of the method as a tool and source of information for the administration.

Steps of activity based costing: Activity-Based Costing depends on the analysis of the activities participating in an organization, supposing that these activities create-consume cost in order for the products or services to be produced.

Thus, in order to obtain the cost information needed, this method not only notes the activities, but also analyses all the elements regarding the time, the way, the resources of each activity or function (a number of activities).

The steps that Activity-Based Costing follows are:

- Recognition of cost objects (the reason of cost analysis)

- Defining the activities that affect each cost object

- Determining the sources of expenses that affect each activity

- Assigning the activities to the cost objects

- Transfer the activity cost to the cost objects and argue on the final results

The cost of activities, with this method, is focused on the cost objects (products, services, customers) with point of report the use of activities by the cost objects. The factors of activity offer useful information to the management with regard to the cost of realization of activities that create cost.

Advantages of activity-based costing: As mentioned before, ABC allocates the General Expenses (GE) (Overhead Cost) first to the activities (that create them). And in the next stage, are being transferred to the products depending on which activities and how much they influence the particular products. This way of cost spreading provides the following advantages over the traditional costing method:

- The expenses are analyzed with greater detail than the traditional methods where the expenses are only categorized as direct and indirect

- While traditional cost methods group the General Expenses (GE) (Overhead Cost) in the general cost-centers such as those of Production, Administration, Disposal, Services and Research and then, distribute them to the products; ActivityBased Costing categories them according to the activities that consume them

- Activity-Based Costing analyses all the activities, providing information to the administration of 


\section{J. Social Sci., 6 (3): 376-382, 2010}

those activities that contribute less, or, cost more than they should, letting the managers abolish some of them

- Detailed Activity and cost analysis present a great help for creating better budgets

\section{MATERIALS AND METHODS}

Prefecture of Grevena of Greece consists of 13 Divisions and 4 departments. The research that follows begins with the data from the Internal Office of the Prefecture. Initially through personal interviews of the general director and key employees, there has been noted the way the Prefecture works and whether it follows the official working structure. After confirming that everything functions as planned, the financial economic data of the departments was requested. This data includes the employee payroll of the year 2007, the expenses of every division and department and the inventory of the fixed assets.

Thereafter, the researchers recorded the working $h$ of each employee as well as the total number of services that each department provided along with the number of customers-citizens that were served.

Then, follows the creation of a model based on the international bibliography and practice. The model relies on the principals of Activity-Based Costing and analyzes in detail:

- The resources of the Prefecture and its cost (wages of employees, the expenses of telecommunication, of water supply, of electricity, of cleaning, of stationery, the supply of books, periodicals and newspapers, the supply of detergents, the expenses for heating, for supplies and the depreciation of fixed assets)

- The departments and the activities

Before starting with the research, it is essential to quote the elements of Activity-Based Costing model when applied on Public Service Sector. The cost-object of a service sector organization could be the cost of a service provided (including all kind of services provided by each Division or Department of Public Sector). In our case, these services could be the receipt of an application and the forwarding to the Central Administration Office, or, the edition of a building license from the Urban Division, or the edition of a driving license from the Traffic and Transportation Division. These services need some activities to be taken place and these activities need recourses. As recourses, are the employees and their salaries, the fixed assets and their depreciation and all the other general expenses. The cost of each service provided can be estimated when calculating the cost of each activity and at the same time connect the activities to each service provided.

After quoting the general elements of an ActivityBased Costing model, it is necessary to focus on the stages of research and application of $\mathrm{ABC}$ in the Prefecture of Grevena. The first stage has to do with the recognition of cost objects; such can be the cost analysis of each department, the cost of each service, or, the cost of each customer-citizen serviced.

In the 2nd stage, the aim is to determine the activities that affect each cost object. Prefecture of Grevena has Divisions and Departments. Each Division has its own Departments. Each Department has a Main Function (the Service provided) that needs a number of activities to be performed. At this point, the scope of this research is to note the departments and the activities in each department, so as to create a full Activity table of the prefecture easily understood by every reader.

In the 3rd stage, the researchers need to determine the resources (expenses) that affect each activity and categorize them (direct, indirect expenses), in order to calculate the cost of each activity in the next stage. In the next stage, each activity is connected with the costpools and obtains its cost. After that, each cost object is connected with the activities that participate along with their cost. The final stage is to concentrate the cost for each cost-object to be analyzed.

All those stages are implemented on the Division of Economic Services as shown below:

- The Division of Economic Services is divided to Departments according to Internal Office

- Our research analysis consists of all the Departments of the Division of Economic Services. There are 4 departments and a Secretariat Office

- A record follows of all the activities of every department. The Internal Office of the Prefecture sets the primary activities of each department. It is necessary to check that the activities performed are according to the primary ones and since everything works as should, the writers define the cost-objects for the analysis such as the "payment of a cheque"

- The activities need resources as means of pursuance, such as the assets used, the salaries of the employees and other operational expenses

- After allocating the resources, it is needed to set the cost drivers, the rules that connect expenses and activities, so as to have a first estimation of the cost of activities. In this case, the main rule is the work hours needed for each activity 
- The next step is to allocate the cost of resources to the activities according to cost-drivers

- At this point, the activities carry cost and it is crucial to connect them to the cost-objects with the assistance of the activity-drivers, that bind activities to cost-objects

- The last stage is to create a final table of all the activities and the primary cost-object, which is the cost of each customer-citizen that the Department of Economic Services served during the specific time-period

The sequence of this method is quite simple. Every department provides some services. Thus, in order to make a cost analysis of each department, it is needed to estimate the cost of each activity and convey it to the services provided or the customers served.

The outcome of this process is the cost analysis of all activities, services and departments. This analysis is forwarded to the Head Administrator for decision making.

\section{Implementation of activity-based costing:}

Analysis of the division of economic services of: The prefecture of Grevena. The mission of the Division of Economic Services is the reassurance of the necessary resources and revenues for the Prefecture, the record, the development and the protection of the assets of the Prefecture, the payment of the cheques, the creation of the next year's budget and the creation of the statement of accounts and balance sheet.

The specific division consists of the following departments:

- Budget Department

- Revenues and Payment Department

- Assets and Procurement Department

- Expenses Audit Department

- Secretarial Department

Resources analysis: The Annual Statement of Accounts is the official source of information regarding financial data of the Prefecture. These figures are the number of the employees, their salaries, the operational expenses of the department and the fixed assets with their depreciation.

The real Annual Statement of Accounts (only the expenses) for 2007 is as follows.

Table 1 shows concisely all the expenses for the Division of Economic Services. It is thought to be useful to include the total expenses of the Prefecture at the same table, in order to have a figure of how much in percentage are the expenses of the specific division to those spent for the whole organization. The expenses of Division of Economic Services (without the depreciation cost) are $4.13 \%$ of the total expenses.

At this point, it is necessary to set the Limitations of the Research that follows:

- Although the whole cost of the Division is presented, the research analyses thoroughly only the Revenues and Payment Department

- The cost-object has to do with the cost (direct and indirect) of each customer-citizen of the specific Division

- The employees of whole Division are 7and 2 of them study for the Revenues and Payment Department

- The weekly working timetable is $35 \mathrm{~h}$ while for the year is $1,820 \mathrm{~h}$ (52 weeks)

- The actual daily working timetable is $7.5 \mathrm{~h}$ which means $37.5 \mathrm{~h}$ week $^{-1}$. The researchers decided to consider as a weekly working timetable the $35 \mathrm{~h}$ and NOT the $37.5 \mathrm{~h}$, to integrate the annual vacation period of the employees of the Division

- The actual daily working timetable was figured through personal interviews

- The direct cost consists of only the employees' salaries

- The indirect cost includes the depreciation of the fixed assets (PCs, office machines and furniture)and is spread to the employees according to how these assets are used

Table 1: Annual statement of accounts of 2007 for division of economic services (in euro)

\begin{tabular}{|c|c|c|c|}
\hline Categories & Account & $\begin{array}{l}\text { Division } \\
\text { total }(€)\end{array}$ & $\begin{array}{l}\text { Prefecture } \\
\text { total }(€)\end{array}$ \\
\hline 1. & Employees' Salaries & $149,471.28$ & $3,636,509.77$ \\
\hline 2. & $\begin{array}{l}\text { Telecommunication } \\
\text { expenses }\end{array}$ & $2,700.00$ & $38,400.00$ \\
\hline 3. & $\begin{array}{l}\text { Water-supply-irrigation } \\
\text { expenses }\end{array}$ & 50.00 & $1,420.00$ \\
\hline 4. & Lighting expenses & $3,100.00$ & $63,046.00$ \\
\hline 5. & Cleanness expenses & $2,500.00$ & $126,900.00$ \\
\hline 6. & $\begin{array}{l}\text { Expenses for supply of } \\
\text { stationery }\end{array}$ & $1,700.00$ & $22,091.00$ \\
\hline 7. & $\begin{array}{l}\text { Expenses for the supply } \\
\text { of books, periodicals } \\
\text { and newspapers }\end{array}$ & $1,200.00$ & $5,467.00$ \\
\hline 8. & $\begin{array}{l}\text { Expenses for the supply } \\
\text { of detergents }\end{array}$ & 320.00 & $17,330.00$ \\
\hline 9. & Expenses for heating & $4,500.00$ & $93,350.00$ \\
\hline 10. & $\begin{array}{l}\text { Expenses for operational } \\
\text { supplies }\end{array}$ & 700.00 & $18,580.00$ \\
\hline 11. & $\begin{array}{l}\text { Expenses for the supply } \\
\text { of personal heating } \\
\text { devises }\end{array}$ & 240.00 & $4,415.00$ \\
\hline \multirow[t]{2}{*}{12.} & $\begin{array}{l}\text { Depreciation of } \\
\text { fixed assets }\end{array}$ & $5,550,35$ & - \\
\hline & Total & $172,031.63$ & 4.027.508.77 \\
\hline
\end{tabular}


- The miscellaneous cost includes the telecommunication expenses, the water-supply irrigation expenses, the lighting expenses, the cleanness expenses, the expenses for supply of stationery, the expenses for the supply of books, periodicals and newspapers, the expenses for the supply of detergents, the expenses for heating, the expenses for operational supplies and the expenses for the supply of personal heating devises. These expenses are spread to the 7 employees equally

- The number of customers served in 2007 was 2,956

- The salary figures are real

- The expenses figures are real

- Depreciation of the fixed assets has been calculated only for the research and according to the Greek Accounting Standards

- In 2007, there were 2,286 checks (bank notes) paid, 519 times that employees collected revenues for the Prefecture and 1,019 accounting records of all the transaction

The aim is to connect the theoretical methodology (as shown in the previous chapter) with the practical implementation. Thus, the next step is to define the cost drivers and to connect the cost to the activities.

\section{RESULTS}

At this part of the research the cost analysis of the department starts with the following step.
The Table 2 applies these steps, meaning that they show the activities of the department, the weekly and yearly working timetable, total costs of salaries and the spread of this cost to all activities of the Revenues and Payment Department.

Table 3 and 4 are similar showing the activities of each employee that works in the Revenues and Payment Department (there are only 2 employees). Table 3 and 4 also show the hours that each employee spends per week or year on each activity. The columns mentioning the salaries and other expenses are calculated as the following example.

Employee No. 1 gets $€ 21,538.50$ per year and he is occupied on three activities spending $1,612 \mathrm{~h} \mathrm{year}^{-1}$ $(1,300 \mathrm{~h}$ for the first activity). Dividing his salary to the working hours $(€ 21,538.50 / 1,612=€ 13.36)$, the hourly cost is calculated. Then, multiplying the hours used for his main activity by the hourly cost $(€ 13.36 * 1,300=$ $€ 17,369.76$ ), the cost for his main activity (cash a cheque) is figured. Having in mind the previous tables, there is a working time "gap" between the hours that actually the two employees have worked and the limitation mentioned $\left(35 \mathrm{~h}_{\text {week }}{ }^{-1}\right)$. This gap can be explained by secondary activities performed not shown in the Activity Map of the Internal Office. These activities are discovered after the personal interviews of the employees. Such activities are the filing of the papers and the public relations.

Table 2: Implementation of activity-based costing

i. Defining the activities of the department and the employees that study in order these activities to be performed

ii. Calculating the cost that each activity carries.

iii. Setting the weekly working timetable that each employee spends for each activity

iv. Measuring the cost of each activity depending on the working $h$ that each employee needs for each activity

v. All the above steps calculate the cost of salaries for each employee

vi. Allocating the cost of each employee to the department that is engaged and to the activities that performs. There may be 2 or more employees for one activity executed

vii. Transferring the total cost of each activity to the cost-objects affected

viii. Concluding with the total cost of the cost objects.

Table 3: Employee No. 1 of the revenues and payment department

\begin{tabular}{llllll}
\hline Activity & $\begin{array}{l}\text { Hourly occupation } \\
\text { per year }\end{array}$ & $\begin{array}{l}\text { Hourly occupation } \\
\text { per week }\end{array}$ & $\begin{array}{l}\text { Employee } \\
\text { salary }(€)\end{array}$ & $\begin{array}{l}\text { Depreciation } \\
\text { cost }(€)\end{array}$ & $\begin{array}{l}\text { Miscellaneous } \\
\text { cost }(€)\end{array}$ \\
\hline Cash a cheque (payment) & 1,300 & 25 & $17,369.76$ & 714.52 & $1,959.68$ \\
Revenues collection accounting & 208 & 4 & $2,779.16$ & 114.32 & 313.55 \\
Record of all transactions & 104 & 2 & $1,389.58$ & 57.16 & 156.77 \\
Total & 1,612 & 31 & $21,538.50$ & 886.00 & $2,430.00$ \\
\hline
\end{tabular}

Table 4: Employee No. 2 of the revenues and payment department

\begin{tabular}{|c|c|c|c|c|c|}
\hline Activity & $\begin{array}{l}\text { Hourly occupation } \\
\text { per year }\end{array}$ & $\begin{array}{l}\text { Hourly occupation } \\
\text { per week }\end{array}$ & $\begin{array}{l}\text { Employ EE } \\
\text { salary }(€)\end{array}$ & $\begin{array}{l}\text { Depreciation } \\
\operatorname{cost}(€)\end{array}$ & $\begin{array}{l}\text { Miscellaneous } \\
\text { US cost }(€)\end{array}$ \\
\hline Cash a cheque (payment) & 1,040 & 20 & $23,873.50$ & 775.50 & $2,430.00$ \\
\hline Total & 1,040 & 20 & $23,873.50$ & 775.50 & $2,430.00$ \\
\hline
\end{tabular}




\section{J. Social Sci., 6 (3): 376-382, 2010}

Table 5: Costing the revenues and payment department

\begin{tabular}{|c|c|c|c|c|c|c|c|c|c|}
\hline Activity & $\begin{array}{l}\text { Hourly occupation } \\
\text { per year }\end{array}$ & $\begin{array}{l}\text { Hourly occupation } \\
\text { per week }\end{array}$ & $\begin{array}{l}\begin{array}{l}\text { No. of } \\
\text { personnel }\end{array} \\
\end{array}$ & Fixed assets & $\begin{array}{l}\text { Direct } \\
\operatorname{cost}(€)\end{array}$ & $\begin{array}{l}\text { Indirect } \\
\operatorname{cost}(€)\end{array}$ & $\begin{array}{l}\text { Miscellaneous } \\
\operatorname{cost}(€)\end{array}$ & $\begin{array}{l}\text { Annual } \\
\operatorname{cost}(€)\end{array}$ & $\begin{array}{l}\text { Annual cost } \\
\text { per activity }(€)\end{array}$ \\
\hline $\begin{array}{l}\text { Cash a cheque } \\
\text { (payment) }\end{array}$ & 2,340 & 45 & $\frac{1}{2}$ & $\begin{array}{l}\text { Office (2), Table of } \\
\text { reception (1) } \\
\text { Bookcase (2), Chair (2) } \\
\text { Drawer (4), Chair for } \\
\text { public (6), } \\
\text { Bookshelf (1), PC (2) } \\
\text { Printer (3), Printer for } \\
\text { checks (1), Fax (1) } \\
\text { Telephone (2) }\end{array}$ & $41,243.26$ & $1,490.02$ & $4,389.68$ & $47,122.96$ & 20.61 \\
\hline $\begin{array}{l}\text { Revenues } \\
\text { collection }\end{array}$ & 208 & 4 & 1 & $\begin{array}{l}\text { Table (1), Table of } \\
\text { reception (1) } \\
\text { Bookcase (1), Chair (1) } \\
\text { Drawer (2), Chair for } \\
\text { public (3), PC (1) } \\
\text { Printer (1), Check } \\
\text { printer (1), Telephone (1) }\end{array}$ & $2,779.16$ & 114.32 & 313.55 & $3,207.08$ & 6.18 \\
\hline $\begin{array}{l}\text { Accounting } \\
\text { record of all } \\
\text { transactions }\end{array}$ & 104 & 2 & 1 & $\begin{array}{l}\text { Table (1), Table of } \\
\text { reception (1) } \\
\text { Bookcase (1), Chair (1) } \\
\text { Drawer (2), Chair for } \\
\text { public (3), PC (1) } \\
\text { Printer (1), Check } \\
\text { printer (1), Telephone (1) }\end{array}$ & $1,389.58$ & 57.16 & 156.77 & $1,603.51$ & 1.57 \\
\hline Total & 2,652 & 51 & & & $45,412.00$ & $1,661.50$ & $4,860.00$ & $51,933.50$ & \\
\hline
\end{tabular}

Table 6: Total cost of the division of economic services

\begin{tabular}{|c|c|c|c|c|c|}
\hline Departments & $\begin{array}{l}\text { Hourly occupation } \\
\text { per year }\end{array}$ & No. of employees & $\begin{array}{l}\text { Annual cost } \\
(€)\end{array}$ & $\begin{array}{l}\text { Quantity of activities } \\
\text { performed }\end{array}$ & $\begin{array}{l}\text { Annual cost per } \\
\text { activity performed }(€)\end{array}$ \\
\hline \multicolumn{6}{|l|}{ Budget Department } \\
\hline Compilation or alteration of budget & 104 & 1 & $1,691.08$ & 8 & 211.38 \\
\hline $\begin{array}{l}\text { Compilation of balance-sheet and statement } \\
\text { of profit/loss accounts }\end{array}$ & 52 & 1 & 845.56 & 1 & 845.56 \\
\hline $\begin{array}{l}\text { Auditing of all supporting documents for } \\
\text { expenses and emission of payment cheques }\end{array}$ & 3,120 & 2 & $45,214.79$ & 5,231 & 8.64 \\
\hline Accounting record of all transactions & 104 & 1 & $1,323.20$ & 5,231 & 0.25 \\
\hline Total & 3,380 & & $49,074.63$ & & \\
\hline \multicolumn{6}{|l|}{ Revenues and Payment Department } \\
\hline Cash a cheque (payment) & 2,340 & 2 & $47,122.96$ & 2,286 & 20.61 \\
\hline Collecting the revenues & 208 & 1 & $3,207.08$ & 519 & 6.18 \\
\hline Accounting record of all transactions & 104 & 1 & $1,603.51$ & 1,019 & 1.57 \\
\hline Total & 2,652 & & $51,933.50$ & & \\
\hline \multicolumn{6}{|l|}{ Assets and Procurement Department } \\
\hline $\begin{array}{l}\text { Compilation and observation of the } \\
\text { program for the supply of materials or other } \\
\text { asset for the prefecture's needs }\end{array}$ & 1,560 & 1 & $19,981.10$ & - & - \\
\hline Public competitions for nominating a supplier & 208 & 1 & $2,664.15$ & 6 & 444.03 \\
\hline Total & 1,768 & & $22,645.25$ & & \\
\hline \multicolumn{6}{|l|}{ Expenses Audit Department } \\
\hline $\begin{array}{l}\text { Audit of the expenses, settlement of } \\
\text { expenses, emission }\end{array}$ & 1,560 & 1 & $24,471.15$ & 2,088 & 11.72 \\
\hline
\end{tabular}

The Table 5 shows the full cost analysis of the activities and the department.

Furthermore, the same steps have been followed for the other departments of the Division of Economic Services. The Table 6 is a combined table of the cost estimation results of the whole division.

\section{DISCUSSION}

Table 7 shows a result of $€ 58.19$ that each customer cost to the specific division of Prefecture of Grevena. This outcome is according to the new cost estimation model. If we used Table 1 (Annual
Statement of Accounts) and divided that to the customers served in $2007(€ 172,031.63 / 2,956=$ $€ 58.197)$, the result would be the same and that method is the traditional costing.

The main difference between traditional and Activity-Based Costing is shown in the Table 3-7. Table 3-7 analyze the Division of Economic Services in many levels. It is crucial to argue that traditional cost accounting does not give information regarding the reasons of cost created. Thus, Activity-Based Costing works complementary providing detailed cost information to administration for further analysis and proper decision making. 
Table 7: Total annual cost per customer

\begin{tabular}{lllc}
\hline Department & $\begin{array}{l}\text { No. of } \\
\text { employees }\end{array}$ & $\begin{array}{l}\text { Total cost per } \\
\text { department }(€)\end{array}$ & $\begin{array}{c}\text { Cost per customer } \\
\text { per department }(€)\end{array}$ \\
\hline $\begin{array}{l}\text { Budget Department } \\
\text { Revenues and }\end{array}$ & 2 & $49,074.63$ & 16.60 \\
$\begin{array}{l}\text { Payment Department } \\
\text { Assets and Procurement }\end{array}$ & 1 & $51,933.50$ & 17.57 \\
$\begin{array}{l}\text { Department } \\
\text { Expenses Audit }\end{array}$ & 1 & $22,645.25$ & 7.66 \\
$\begin{array}{l}\text { Department } \\
\text { Secretarial Department } \\
\text { Total }\end{array}$ & 1 & $25,286.85$ & 8.55 \\
\hline
\end{tabular}

\section{CONCLUSION}

The main purpose of this article was to present the basic principles and procedures of Activity-Based Costing and to examine whether the implementation of this method is possible to a Public Sector Organization.

From all the above, the key characteristics of the new method are shown with great detail, along with the capabilities to provide information regarding the cost estimation, so that can be easily used by the administration for identifying the bottlenecks. Especially, Table 3 and 4 of the employees of the Revenues and Payment Department, where the performance of the two employees can be increased and this is obvious to the managers.

Furthermore, through this analysis Prefecture of Grevena can extend the method implementation to all its Divisions, targeting to create a full image of the cost of the Prefecture and to apply corrective actions (Activity-Based Management).

The data tables created were given to administration, although the actions to be taken are not an area for Activity-Based Costing but for its improvement method Activity-Based Management. The outcome was for a confidential report to be written and sent to the Greek Ministry of Home Department. If the Prefecture was a private company many changes could be made, such as minimizing the working "gap" of the specific employees by creating new services for customers, or, by letting go one of them, but as a Public Sector organization the "Chairman" is the Minister and politics did not let him make any changes.

Finally, this research can be used as a pilot in any attempt of implementing Activity-Based Costing in Public Sector. The use of this method with the cooperation of new technologies and new methods of management, can resolve all the deficiencies of Public Sector, so as citizens and companies will be better served.

\section{REFERENCES}

Brimson, J.A. and J. Antos, 1994. Activity-Based Management for Service Industries, Government Entities and Non-Profit Organizations. 1st Edn., John Wiley and Sons, Inc. New York, ISBN: 10: 047101351X, pp: 364.

Evans, P. and S. Bellamy, 1995. Performance evaluation in the Australian public sector; the role of management and cost accounting control systems. Int. J. Public Sector Manage., 8: 30-38. DOI: 10.1108/09513559510100006

Kaplan, R.S., 1994. Management accounting (19841994): Development of new practice and theory. Manage. Account. Res., 5: 247-260.

King, M., 1995. Activity Based Costing in Hospitals-A Case Study Investigation. CIMA Publishing, London, UK., ISBN: 10: 1874784256, pp: 66.

Kirche, T.E., 2002. A comparison of activity-based costing and the theory of constraints-based approaches for profitability analysis in order management and production planning decisions. Ph.D. Dissertation, University of Houston.

Kostopoulos, X., N. Karapostolis, N. Polyzos, B. Mbardis and D. Mbartzokas et al., 2003. Cost of the daily services of a psychiatric facility. Psychiatry, 14: 121-135.

Municipality of Argyroupolis, 2005. Activity based costing. Municipal Development Company of Argyroupolis. http://www.deada.gr/index.php?option=com_conte nt\&task $=$ view $\&$ id $=57 \&$ Itemid $=74$

Tsialta, A., 2009. Costing public sector. MSc Dissertation, University of Macedonia. http://dspace.lib.uom.gr/bitstream/2159/13386/2/Ts ialtaMsc2009.pdf

Vazakidis, A. and I. Karagiannis, 2006. Activity-based costing in higher education: A study of implementing activity-based costing in University of Macedonia. Proceeding of the 5th Conference of the Hellenic Finance and Accounting Association, Dec. 15-16, ScientificCommens, Thessaloniki, Greece, $\quad$ pp: 1-1. http://en.scientificcommons.org/41575796

Vazakidis, A. and I. Karagiannis, 2009. Activity-based management and traditional costing in tourist enterprises (a hotel implementation model). Oper. Res. DOI: 10.1007/s12351-009-0049-3 